\title{
PENGARUH PENDEKATAN KETERAMPILAN PROSES DAN MOTIVASI BELAJAR TERHADAP HASIL BELAJAR ILMU PENGETAHUAN ALAM (IPA) TERPADU
}

\author{
${ }^{1}$ Khairan Muhammad Ari \& ${ }^{2}$ Dadan Sumardana \\ 1e-mail: khairanarif@gmail.com \\ 2e-mail: dadan@gmail.com \\ Prodi Magister Teknologi Pendidikan UIA Jakarta
}

Jl. Jati Waringin, Pondok Gede, Jakarta Timur

\begin{abstract}
Abstrak: Penelitian ini bertujuan mengetahui perbedaan pengaruh keterampilan proses dan tingkat motivasi belajar terhadap hasil belajar IPA Terpadu. Juga untuk mengetahui ada tidaknya interaksi antara kedua variabel tersebut terhadap hasil belajar IPA Terpadu. Penelitian ini menggunakan metode eksperimen dengan populasi seluruh siswa kelas VIII di SMP Negeri 2 Tegalwaru Purwakarta. Sampel diambil dengan simple random sampling berdasarkan factorial group desain, sehingga siswa terpilih 76 siswa. Untuk pengujian hipotesis digunakan teknik analisis varians 2 jalur (anava $2 \times 2$ ) dengan taraf signifikansi a $=0,05$ dengan terlebih dahulu uji normalitas dengan liliefors dan homogenitas data dengan levene. Hasil pengujian statistik menunjukkan bahwa data ketiga variabel normal dan homogen. Hasil penelitian ini menunjukkan bahwa belajar melalui pendekatan pembelajaran keterampilan proses lebih tinggi daripada siswa yang dibelajarkan dengan tidak melalui pendekatan keterampilan proses, dan hasil belajar IPA terpadu kelompok siswa yang memiliki motivasi tinggi lebih tinggi dibanding siswa yang memiliki motivasi rendah, juga terdapat interaksi yang nyata antara pendekatan keterampilan proses dengan motivasi terhadap hasil belajar IPA terpadu. Bagi siswa yang mempunyai motivasi rendah harus dilaksanakan pembelajaran dengan pendekatan keterampilan proses.
\end{abstract}

Kata-kata kunci: belajar, keterampilan proses, motivasi, terpadu

\section{THE INFLUENCE OF PROCESS AND MOTIVATION SKILLS APPROACH TO LEARNING TOWARDS THE LEARNING RESULTS OF NATURAL SCIENCE (IPA)}

\begin{abstract}
This research aims to know the differences of the influence Process Skills and the level of motivation of learning towards the Learning Outcomes of the integrated IPA. Also to find out whether there are interactions between the two aforementioned variables against the learning outcomes of the integrated Natural Science. This research uses experimental methods with the entire population of grade VIII in SMP Negeri 2 Tegalwaru Purwakarta. Samples are taken with a simple sampling based on factorial randon group design. So the students elected 76 students. For testing the hypotheses used analysis of variance techniques 2 lanes (Anava $2 \times 2$ ) significance level $\alpha=0.05$ with first test of normality with its homogeneity and liliefors data with levene. Statistics show that the test results of the third variable data normally and homogeneous. The results of this study indicate that learning through learning approach, process skills higher than dibelajarkan students with skill approach not through the process, and the results of learning IPA integrated groups of students who have high motivation is higher than students who have low motivation, there is a real interaction between the process of with motivation skills approach towards learning outcomes the integrated IPA. For students who have low motivation of learning should be implemented with the approach of the process skills.
\end{abstract}

Keywords: process skills, motivation, learning, integrated 


\section{PENDAHULUAN}

Dalam Undang-Undang Sisdiknas Nomor 20 Tahun 2003 tentang Sistem Pendidikan Nasional, pasal 3 dinyatakan bahwa; "Pendidikan nasional berfungsi mengembangkan dan membentuk watak serta peradaban bangsa yang bermartabat dalam rangka mencerdaskan kehidupan bangsa, bertujuan untuk berkembangnya potensi siswa agar menjadi manusia yang beriman dan bertakwa kepada Tuhan Yang Maha Esa, berakhlak mulia, sehat, berilmu, cakap, kreatif, mandiri, dan menjadi warga negara yang demokratis serta bertanggung jawab".

Dengan memperhatikan isi UU No. 20 tahun 2003 tersebut, peneliti berpendapat bahwa tugas para guru dan para pendidik sangat berat, sebab kemajuan suatu bangsa ditentukan oleh keberhasilan pendidikan dari bangsa itu sendiri. Jika seorang guru atau pendidik gagal mengembangkan potensi siswa, maka dapat dipastikan suatu negara tidak akan mengalami kemajuan, sebaliknya bila guru atau pendidik berhasil mengembangkan potensi siswa, maka akan lahir sumber daya manusia yang cerdas, terampil, dan berkualitas.

Ilmu Pengetahuan Alam (IPA) Terpadu telah mengalami perkembangan dan kemajuan sangat pesat, seiring dengan kemajuan Ilmu Pengetahuan dan Teknologi, sehingga hal mendorong para pendidik untuk dapat merancang dan melaksanakan pendidikan yang lebih terarah pada penguasaan konsep IPA TERPADU yang dapat meningkatkan kualitas kegiatan pembelajaran ilmu ini di dunia pendidikan. Oleh karena itu, dalam rangka menghadapi pesatnya perkembangan IPA TERPADU, maka usaha untuk meningkatan kreatifitas sumber daya manusia menjadi sangat penting dan vital, dan jalur yang tepat untuk meningkatkan sumber daya manusia diberbagai negara adalah melalui jalur pendidikan dan pembelajaran yang berkualitas.

Ilmu Pengetahuan Alam (IPA) adalah ilmu pengetahuan yang berkaitan dengan alam semesta. Ilmu Pengetahuan Alam tidak hanya menuntut para siswa untuk sekedar terampil dalam melakukan percobaan-percobaan di laboratorium, tetapi IPA lebih menekankan kemampuan intelektual siswa dalam memahami Natural Sains.

Pembelajaran IPA TERPADU adalah pembelajaran yang berisi tema-tema yang sangat esensial, actual serta global yang berkembang dalam kemajuan teknologi masa kini, sehingga mata pelajaran dan pengetahuan IPA ini merupakan pengetahuan yang dapat mewarnai perkembangan kehiduapan manusia. Ilmu Pengetahuan Alam adalah ilmu yang berupa fakta, konsep dan teori yang dapat menjelaskan gejala-gejala kehidupan. Pengembangan pembelajaran IPA TERPADU bukan hanya sekedar menguji dan menjelaskan kumpulan fakta, teori ataupun konsep, tetapi juga menguji dan menjelaskan hal-hal yang terkait dengan kumpulan proses dan nilai yang dapat diaplikasikan serta dikembangkan dalam kehidupan nyata.

Dalam Kurikulum Tingkat Satuan Pendidikan (KTSP) (KTSP: 2007). Ilmu Pengetahuan Alam (IPA) berkaitan dengan cara mencari tahu fenomena alam secara sistematis, sehingga IPA bukan hanya penguasaan kumpulan pengetahuan yang berupa fakta-fakta, konsep-konsep, atau prinsip-prinsip semata, akan tetapi merupakan proses penemuan. Dalam panduan KTSP juga dijelaskan bahwa pembelajaran IPA TERPADU menekankan pada pemberian pengalaman langsung kepada siswa untuk mengembangkan kompetensinya, sehingga mereka mampu menjelajahi dan memahami alam sekitar secara alamiah.

Adapun mata pelajaran IPA di SMP/MTs bertujuan agar siswa memiliki kemampuan sebagai berikut:

a. Meningkatkan keyakinan terhadap kebesaran Tuhan Yang Maha Esa berdasarkan keberadaan, keindahan dan ketentraman alam ciptaan-Nya.

b. Mengembangkan pemahaman tentang berbagai macam gejala alam, konsep dan prinsip IPA yang bermanfaat dan dapat diterapkan dalam kehidupan sehari-hari.

c. Mengembangkan rasa ingin tahu, sikap positif, dan kesadaran terhadap adanya hubungan yang saling mempengaruhi antara IPA, lingkungan, teknologi, dan masyarakat.

d. Melakukan percobaan ilmiah untuk menumbuhkan kemampuan berpikir, bersikap dan bertindak ilmiah serta berkomunikasi.

e. Meningkatkan kesadaran untuk berperan serta dalam memelihara, menjaga, dan melestarikan lingkungan serta sumber daya alam.

f. Meningkatkan kesadaran untuk menghargai alam dan segala keteraturannya sebagai salah satu ciptaan Tuhan.

g. Meningkatkan pengetahuan, konsep, dan keterampilan IPA sebagai dasar untuk melanjutkan pendidikan ke jenjang berikutnya. (KTSP: 2007).

Dari keterangan dan fakta-fakta di atas, maka pembelajaran IPA TERPADU ini menjadi sangat 
penting untuk dikembangkan dan ditingkatkan kualitasnya dalam sekolah-sekolah di Indonesia. Oleh karena itu, penulis termotivasi melakukan penelitian ini dalam rangka meningkatkan hasil belajar Mata Pelajaran ini di sekolah peneliti. Data menunjukkan bahwa nilai hasil belajar IPA TERPADU ini belum mencapai KKM, sebagaimana tabel 1 berikut:

Tabel 1

Rekapitulasi Rata-rata Nilai Ulangan Akhir Semester Ganjil Mata Pelajaran IPA TERPADU Kelas VIII SMP

Negeri 2 Tegalwaru Tahun Pelajaran tahun 2013-2018

\begin{tabular}{|c|c|c|c|c|}
\hline No & $\begin{array}{l}\text { Tahun } \\
\text { Ajaran }\end{array}$ & $\begin{array}{c}\text { Rata-rata Nilai } \\
\text { Hasil Belajar } \\
\text { Ujian Akhir } \\
\text { Semester } \\
\text { Pelajaran IPA } \\
\text { TERPADU }\end{array}$ & KKM & Ket.(\%) \\
\hline 1 & $2013-2014$ & 6,00 & 6,50 & $60 \%$ \\
\hline 2 & 2015-2016 & 6,50 & 7,00 & $65 \%$ \\
\hline 3 & $2017-2018$ & 7,00 & 7,40 & $70 \%$ \\
\hline
\end{tabular}

Sumber: SMP Negeri 2 Tegalwaru.

Belajar diartikan sebagai proses perubahan tingkah laku pada diri individu karena adanya interaksi antara individu dan individu dengan lingkungannya. Burton menyatakan, "Learning is change in the individual due to instruction of that individual and this environment, which fells a need and makes him more capable of dealing and his environment," (W.H Burton,The Guidance of Learning Activities, dalam Uzer: 1944). Dalam pengertian ini terdapat kata "change", atau "perubahan", yang berarti bahwa seseorang telah mengalami proses tingkah laku, baik dari aspek pengetahuannya, keterampilannya, maupun aspek sikapnya. Belajar menurut aliran psikologi kognitif adalah "Perubahan dalam pengetahuan, karenanya mereka berpendapat bahwa belajar adalah suatu aktivitas internal mental, seperti berfikir, mengingat dan lain-lain" (Woolfolk: 1993). Belajar adalah suatu perubahan yang terjadi dalam diri organisme, manusia dan hewan disebabkan oleh pengalaman yang dapat mempengaruhi tingkah laku organisme tersebut (Sulistyorini: 2009). Menurut Kemp, tujuan belajar dapat dikelompokkan ke dalam tiga kawasan yaitu; Kognitif, Psikomotorik dan Keterampilan" (Kemp: 1977).

Dari pengertian di atas disimpulkan bahwa belajar adalah suatu proses perubahan tingkah laku individu, melalui interaksi dengan lingkungannya. Perubahan tingkah laku dalam pembelajaran dapat terjadi bila terdapat hasil yang diperoleh dalam diri siswa, berupa perubahan pada pengetahuan, keterampilan dan sikap yang berguna bagi siswa maupun orang lain.

Adapun hasil belajar adalah hasil yang diperoleh dan dicapai seorang siswa, setelah mengikuti dan menempuh proses pembelajaran tertentu dan pada periode waktu tertentu dan dalam mata pelajaran tertentu. Davies berpendapat bahwa hasil belajar tidak sama dengan penampilan kerja (performance), hasil belajar menyangkut perolehan suatu pengetahuan, keterampilan atau sikap, sementara penampilan kerja adalah menyangkut penggunaan pengetahuan dan sikap yang didemonstrasikan" (Davies: 1981).

Gagne dan Brigss dalam Soedijarto mengklasifikasikan hasil belajar menjadi lima macam kemampuan (capability) yaitu; keterampilan intelektual (intellectual skill), strategi kognitif (cognitive strategy), informasi verbal (verbal information), keterampilan motorik (motor skill) dan sikap (attitude). Kelima macam kemampuan ini harus bisa diamati (observable) dan diukur) (measurable) dalam bentuk perilaku seseorang (Sudijarto: 1993).

Benjamin Bloom dalam Anderson and Krathwohl menyatakan bahwa "hasil belajar yang berkaitan dengan kognitif ada enam aspek atau ranah yaitu pengetahuan, pemahaman, aplikasi, menganalisis, evaluasi dan mencipta" (Anderson and Krathwohl: 2001).

Berdasarkan teori-teori di atas, maka pengertian hasil belajar dapat disimpulkan sebagai; "perubahan perilaku secara positif dan kemampuan yang dimiliki siswa dari suatu interaksi dan tindakan belajar dan mengajar, yang berupa hasil belajar intelektual, strategi kognitif, sikap dan nilai, inovasi verbal, dan hasil belajar motorik (Makmun: 1999).

Hasil belajar dalam penelitian ini adalah kemampuan ranah kognitif yang diperoleh siswa setelah menerima pembelajaran IPA Terpadu, dengan Materi Menganalisis pentingnya pertumbuhan dan perkembangan pada mahkluk hidup yang meliputi aspek Pengetahuan (C1), Pemahaman (C2) dan Penerapan (C3).

Adapun pendekatan keterampilan proses adalah pendekatan belajar mengajar yang mengarah pada pengembangan kemampuan dasar berupa mental fisik dan sosial untuk menemukan fakta dan konsep, atau pengembangan sikap dan nilai melalui proses belajar mengajar yang telah mengaktifkan siswa, sehingga mampu menumbuhkan sejumlah keterampilan tertentu pada diri mereka.

Pada petunjuk pelaksanaan proses belajar mengajar dijelaskan pula bahwa yang dimaksud dengan keterampilan proses adalah keterampilan siswa untuk mengelola perolehan belajarnya yang didapat 
melalui proses belajar mengajar dan memberikan kesempatan lebih luas kepada siswa untuk mengamati, menggolongkan, meramalkan, menerapkan, merencanakan, dan mengkomonikasikannya.

Oleh karena itu menurut Johnson keterampilan proses merupakan kemampuan siswa untuk mengelola dan memperoleh pengetahuan dalam proses kegiatan belajar mengajar (KBM), sehingga memberikan kesempatan seluas-luasnya pada siswa untuk mengamati, menggolongkan, menafsirkan, meramalkan, menerapkan, merencanakan penelitian, mengomunikasikan hasil perolehan tersebut." (Johnson, Elaine B.: 2002)

Adapun motivasi, berasal dari kata latin " $M O$ $V E R E$ ", yang berarti dorongan atau daya penggerak. Motivasi ini diberikan kepada manusia, khususnya kepada siswa dan para guru di dalam dunia pendidikan (Hasibuan: 2004). Motivasi merupakan faktor yang sangat besar pengaruhnya pada proses belajar para siswa, tanpa adanya motivasi maka proses belajar akan sulit berjalan dengan lancar.

Menurut jenisnya, motivasi dapat dibagi menjadi dua macam yaitu; motivasi yang bersifat instrinsik dan motivasi ekstrinsik. Motivasi instrinsik adalah motivasi yang berupa dorongan dalam diri siswa untuk mengejar prestasi. Adapun motivasi ekstrinsik adalah motivasi yang perlu dimanipulasi oleh guru atau perancang/pengembang instruksional, sehingga siswa dapat merasakan adanya dorongan untuk mempelajari materi yang diajarkan (Sukamto: 1993).

Motivasi belajar memegang penting dalam memberikan gairah, semangat, meningkatkan usaha, energi, performa, dan rasa senang dalam belajar, sehingga siswa yang mempunyai motivasi belajar tinggi mempunyai energi banyak untuk melaksanakan kegiatan belajar (Uno: 2007). Djaali mengartikan motivasi sebagai kondisi fisiologis dan psikologis yang terdapat dalam diri seseorang yang mendorongnya untuk melakukan aktivitas tertentu guna mencapat tujuan. (Djaali: 2008).

Berdasarkan teori-teori di atas dapat disimpulkan bahwa, motivasi belajar harus muncul dari diri individu para siswa yang terlibat dalam belajar itu sendiri, sehingga akan mendorong mereka untuk melakukan sejumlah kegiatan belajar maupun tugas-tugas lainnya.

\section{METODE PENELITIAN}

Penelitian ini menggunakan metode penelitian kuantitatif dengan jenis penelitian eksperimen, yaitu penelitian yang sistematis, logis dan teliti di dalam melakukan kontrol terhadap suatu kondisi.

Dalam penelitian eksperimen peneliti memanipulasikan sesuatu rangsangan, treatment atau kondisi eksperimental, kemudian mengobservasi pengaruh yang diakibatkan oleh adanya perlakuan atau manipulasi tersebut. (Yatim Riyanto: 2007)

Penelitian eksperimen ini, adalah suatu penelitian dirancang dan dilaksanakan untuk mengumpulkan bukti-bukti yang ada hubungannya dengan hipotesis. Peneliti akan mengidentifikasi tiga ciri yaitu (1) Variabel bebas; (2) Variabel moderator; dan (3) Variabel tergantung.

Sebagaimana yang telah disebutkan di atas, penelitian ini menggunakan rancangan penelitian eksperimen yang melibatkan dua kelompok yaitu kelompok eksperimen dan kelompok kontrol, siswa responden dibagi ke dalam 2 kelompok yakni: (1) kelompok A untuk kelas siswa yang menerapkan strategi belajar dengan pendekatan keterampilan proses; (2) kelompok B untuk kelas siswa yang menerapkan strategi pembelajaran dengan pembelajaran konvensional.

Masing-masing kelompok kelas akan diberikan materi dan pokok bahasan mata pelajaran IPA yang sama, yaitu program semester 1 (satu) dengan menggunakan metode yang berbeda. Durasi waktu untuk bahan, guru dan konsep yang diberikan terhadap keempat kelompok kelas ini adalah sama, sehingga diupayakan semaksimal mungkin kemampuan siswa dalam sampel penelitian bersifat homogen.

Pada akhir penelitian, baik kelompok eksperimen maupun kelompok kontrol diukur dengan memakai alat ukur yang sama. Pada kedua kelompok kelas selanjutnya akan mengikuti evaluasi hasil belajar dengan bahan, waktu pelaksanaan dan dengan alat ukur yang sama, lalu kemudian dinilai skor tertinggi, rata-rata dan skor terendah, lalu setelah itu dilakukan perbandingan secara statistik.

Desain penelitian yang digunakan dalam penelitian ini adalah factorial design, kemudian data yang diperoleh diolah dan hasilnya dibandingkan dengan tabel statistiknya. Melihat faktor-faktor dari masing-masing variabel dalam penelitian ini, maka desain rancangan penelitian menggunakan factorial design $2 \times 2$ seperti tampak pada tabel berikut: 
Tabel 2

Desain Penelitian

\begin{tabular}{ccc}
\hline $\begin{array}{c}\text { Motivasi } \\
\text { Belajar Siswa } \\
(\mathrm{B})\end{array}$ & Pendekatan Keterampilan (A) \\
& Pendekatan & Pembelajaran \\
& Keterampilan \\
& Proses & \\
& $\mathrm{A}^{1} \mathrm{~B}^{1}$ & $\mathrm{~A}^{1} \mathrm{~B}^{2}$ \\
\hline Tinggi (B1) & $\mathrm{A}^{1} \mathrm{~A}^{2}$ & $\mathrm{~A}^{2} \mathrm{~B}^{2}$ \\
\hline Rendah (B2) & & \\
\hline
\end{tabular}

\section{HASIL DAN PEMBAHASAN}

\section{Hasil}

Data dalam penelitian ini diperoleh dari 52 sampel yang dibagi menjadi dua kelompok yaitu; kelompok kontrol (A2=non keterampilan proses) berjumlah 26 sampel dan kelompok eksperimen (keterampilan proses $=$ A1) berjumlah 26 sampel dan hasil belajar IPA terpadu sesuai desain penelitian Faktorial.

Untuk pengujian hipotesis, data hasil belajar yang diperoleh dalam penelitian ini, terlebih dahulu dilakukan uji normalitas dan homogenitas data. Pengujian normalitas dilakukan pada masing-masing data pembelajaran Keterampilan proses maupun tidak (A1 dan A2), kelompok data motivasi belajar (B1 dan B2) dan kelompok data desain penelitian (A1B1) dn (A2B2).

Tabel 3

Uji Normalitas Data

\begin{tabular}{ccccc}
\hline \multirow{2}{*}{$\begin{array}{c}\text { Kelompok } \\
\text { Data }\end{array}$} & \multicolumn{3}{c}{ Kolmogorov-Smirnov* } & \\
\cline { 2 - 3 } & \multicolumn{2}{c}{ (Liliefors Significance Correction) } & \multirow{2}{*}{ Kesimpulan } \\
\cline { 2 - 3 } Atatistic & df & 26 & Sig. & \\
A2 & 0,128 & 26 & 0,200 & Normal \\
B1 & 0,129 & 26 & 0,200 & Normal \\
B2 & 0,115 & 26 & 0,200 & Normal \\
A1B1 & 0,227 & 13 & 0,066 & Normal \\
A2B1 & 0,124 & 13 & 0,200 & Normal \\
A1B2 & 0,122 & 13 & 0,200 & Normal \\
A2B2 & 0,123 & 13 & 0,200 & Normal \\
\hline
\end{tabular}

Untuk pengujian homogenitas data hasil belajar IPA terpadu diolah dengan menggunakan SPSS 17, maka didapatkan hasilnya seperti pada tabel berikut ini.

Tabel 4

Rekapitulasi Hasil Uji Homogenitas Data Penelitian

\begin{tabular}{|c|c|c|c|c|c|}
\hline $\begin{array}{c}\text { Kelompok } \\
\text { Data }\end{array}$ & $\begin{array}{l}\text { Levene } \\
\text { Statistic }\end{array}$ & df1 & Df2 & Sig. & Keterangan \\
\hline $\begin{array}{l}\text { A1 } \\
\text { A2 }\end{array}$ & 1,738 & 1 & 50 & 0,193 & Homogen \\
\hline $\begin{array}{l}\text { B1 } \\
\text { B2 }\end{array}$ & 0113 & 1 & 50 & 0,738 & Homogen \\
\hline $\begin{array}{l}\text { A1B1 } \\
\text { A2B2 } \\
\text { A1B2 } \\
\text { A2B2 }\end{array}$ & 0,651 & 3 & 48 & 0,586 & Homogen \\
\hline
\end{tabular}

Levene's (uji homogenitas) digunakan untuk mengetahui apakah varian antar kelompok data adalah sama. Kriteria yang digunakan,yaitu jika signifikansi <0,05 maka dapat disimpulkan bahwa varian kelompok data adalah berbeda, sebaliknya jika signifikansi > 0,05 maka disimpulkan bahwa varian kelompok data adalah sama (homogen).

\section{Pengujian Hipotesis}

Dengan terujinya normalitas dan homogenitas data dari hasil belajar IPA terpadu, maka dapat dilanjutkan dengan pengujian hipotesis. Hipotesis statistic dalam penelitian ini diuji dengan menggunakan analisis varians (anava) dua jalur diolah dengan SPSS17. Hasil uji anava dapat dilihat pada tabel 5

Tabel 5

Rekapitulasi Data Hasil Penelitian

\begin{tabular}{|c|c|c|c|c|c|}
\hline Source & $\begin{array}{l}\text { Tyfe III } \\
\text { Sum of } \\
\text { Squares }\end{array}$ & df & $\begin{array}{l}\text { Mean } \\
\text { Square }\end{array}$ & $\mathrm{F}$ & Sig. \\
\hline Corrected Model & $\begin{array}{r}794,827 \\
\text { (a) }\end{array}$ & 3 & 264,942 & 15,288 & 000 \\
\hline Interceft & 42886,327 & 1 & 42886,327 & 2473,515 & 000 \\
\hline MOTIVASI & 549,250 & 1 & 549,250 & 31,693 & 000 \\
\hline KETERAMPILAN & 159,250 & 1 & 159,250 & 9,189 & 004 \\
\hline \multicolumn{6}{|l|}{ PROSES } \\
\hline MOTIVASI * & 86,327 & 1 & 86,327 & 4,981 & 030 \\
\hline \multicolumn{6}{|l|}{ KETERAMPILAN } \\
\hline \multicolumn{6}{|l|}{ PROSES } \\
\hline Error & 831,846 & 48 & 17,330 & & \\
\hline Total & $44,493,000$ & 52 & & & \\
\hline Corrected Total & 1626,673 & 51 & & & \\
\hline
\end{tabular}




\section{Pembahasan}

Perbedaan hasil belajar IPA terpadu siswa yang dibelajarkan melalui Pendekatan Keterampilan Proses (A1) dengan non keterampilan proses (A2).

Pada hipotesis pertama dibuktikan bahwa hasil belajar IPA terpadu yang belajar melalui pendekatan keterampilan proses lebih tinggi daripada siswa yang belajar dengan tidak melalui pendekatan proses (pembelajaran konvensional).

Seperti kita ketahui, bahwa mata pelajaran IPA terpadu adalah salah satu mata pelajaran yang didalamnya banyak konsep, prinsip, prosedur dan fakta. Karena sifatnya yang abstrak, maka unsurunsur ini memiliki tingkat kesulitan tersendiri dalam pemahamannya, oleh karena itu upaya pembelajaran dengan pendekatan keterampilan proses dapat membantu siswa memperoleh hasil belajar yang baik pada mata pelajaran ini.

Hasil penelitian menunjukkan bahwa untuk mencapai tujuan pembelajaran IPA terpadu, pembelajaran dengan pendekatan keterampilan proses lebih efektif dan tepat guna jika dibanding dengan pembelajaran tidak melalui pendekatan keterampilan proses (pembelajaran konvensional). Hal ini disebabkan pembelajaran pendekatan keterampilan proses lebih menarik dan siswa mengalami hal-hal baru dalam proses berlangsung dan sudah pasti dapat memberikan kemudahan dalam memahami konsep, prinsip, prosedur dan fakta. Pembelajaran dengan pendekatan keterampilan proses selain dapat memberikan pengalaman belajar yang lebih konkret dan nyata (bila dibandingkan dengan tidak sama sekali menggunakan pendekatan keterampilan proses pembelajaran konvensional), juga dapat memberikan pengalaman yang lebih bervariasi sehingga menumbuhkan motivasi siswa untuk belajar.

Berdasarkan data skor pendekatan keterampilan proses dalam pembelajaran ini, mempunyai skor ratarata lebih tinggi dari pada tidak melalui pendekatan keterampilan proses (konvensional). Jadi temuan dalam penelitian ini menunjukkan bahwa pembelajaran dengan melalui pendekatan keterampilan proses lebih efektif dalam meningkatkan hasil belajar IPA terpadu dibandingkan dengan tidak melalui pendekatan keterampilan proses (pembelajaran konvensional).

Perbedaan hasil belajar IPA Terpadu siswa yang Mempunyai Motivasi Belajar Tinggi (B1) dan Motivasi Belajar Rendah (B2).
Pada hipotesis kedua dibuktikan bahwa hasil belajar IPA Terpadu siswa yang memiliki motivasi belajar tinggi dibandingkan hasil belajar yang memiliki motivasi rendah. Motivasi merupakan salah satu factor dalam diri siswa yang dapat mempengaruhi hasil belajar. Motivasi belajar merupakan keseluruhan daya penggerak, pendorong dari dalam diri siswa yang menimbulkan kegiatan belajar, menumbuhkan semangat, gairah merasa senang dalam belajar, meningkatkan usaha, menjamin kelangsungan dan arah untuk terus belajar sehingga tujuan yang dikehendaki oleh siswa tercapai. Siswa yang mempunyai motivasi belajar tinggi mempunyai energi banyak untuk melaksanakan kegiatan belajar, unggul diberbagai aktivitas kelas. Lebih mudah menerima atau mengikuti proses pembelajaran, dapat menggunakan potensi-potensi yang dimilikinya secara konstruktif dan produktif untuk mencapai tujuan yaitu hasil belajar yang maksimal dan tujuan belajarnya itu dianggap sebagai kebutuhan yang harus dicapainya.

Adanya motivasi belajar yang tinggi pada diri siswa akan menunjukkan hasil yang baik, dalam arti ada usaha tekun yang disadari motivasi tinggi, maka siswa yang belajar akan melahirkan hasil belajar yang baik. Jadi intensitas motivasi seorang akan sangat menentukan tingkat pencapaian hasil belajarnnya. Motivasi juga mengandung salah satu nilai yang erat kaitannya dengan keberhasilan belajar, yaitu motivasi meningkatkan keberhasilan atau kegagalan belajar siswa. Belajar dengan motivasi rendah sulit untuk mencapai hasil belajar yang maksimal.

Berdasarkan temuan penelitian ini menunjukan bahwa motivasi belajar berpengaruh terhadap hasil belajar siswa.

\section{Pengaruh interaksi Penggunaan Pendekatan Pembelajaran dan Motivasi Belajar terhadap Hasil Belajar IPA terpadu.}

Pada hipotesis ketiga dibuktikan bahwa terjadi interaksi yang nyata antara motivasi belajar dan Pendekatan pembelajaran terhadap rata-rata hasil belajar IPA terpadu.

Hasil uji Tukey pada hipotesis ketiga dan kelima menunjukkan bahwa rata-rata hasil belajar IPA terpadu siswa yang memiliki motivasi tinggi yang belajar dengan melalui pendekatan keterampilan proses lebih besar dibandingkan hasil belajar siswa yang memiliki motivasi belajar tinggi yang dibelajarkan dengan tidak melalui pendekatan keterampilan proses (konvensional) (A1B1>A2B2). Hal ini menunjukkan bahwa kelompok siswa yang memiliki motivasi tinggi 
apabila dengan melalui pendekatan keterampilan proses (variatif) maka mereka akan lebih bersemangat, mudah untuk memahami konsep karena dalam pembelajaran proses seperti ini terdapat visualisasi, fakta dan mengalami serta mencari dan menganalisis, sebagai prinsip dan fakta yang merupakan karateristik dari mata pelajaran IPA terpadu. Media VCD juga dapat meningkatkan pemahaman, dpat menyajikan data dengan menarik, mudah memadatkan informasi belajar karena banyak indera yang terlihat dalam proses pembelajaran, sehingga sangat membantu proses pembelajaran afektif, apa yang dipandang oleh mata dan terdengar oleh telinga dan dilakukan oleh seluruh indera yang bergerak dan melangkah lebih cepat dan lebih mudah diingat daripada yang didengar dan dibaca saja.

Hasil uji Tukey ke empat dan ke enam terlihat bahwa hasil belajar siswa yang memiliki motivasi rendah yang belajarnya melalui pembelajaran pendekatan keterampilan proses tidak berbeda nyata dengan melalui pendekatan non keterampilan proses (konvensional). Dengan demikian pada motivasi belajar rendah dengan media pembelajaran non keterampilan proses tidak terjadi interaksi (A2B1=A2B2, A2B2 = A1B2).

Siswa yang memiliki motivasi rendah mempunyai ciri yaitu perhatian terhadap pembelajaran kurang (tidak dapat fokus), harus dibujuk atau didorong dulu agar melakukan suatau tugas, hanya memperoses informasi secara sepintas lalu, dan seringkali hanya tertarik mengerjakan tugas-tugas yang mudah dan memenuhi persyaratan minimum kelas.

Pelaksanaan pembelajaran dengan pendekatan keterampilan proses pada kelompok siswa yang memiliki motivasi rendah kurang efektif (memberikan hasil yang tidak berbeda dengan pendekatan non keterampilan proses (pembelajaran konvensional) karena pelaksanaan keterampilan proses yang baik, membutuhkan konsentrasi dan belajar nyata dan proses informasi secara cepat didapat sehingga kelompok siswa motivasi rendah mengalami kesulitan mengikutnya dan hasil belajarnyapun tidak mengalami perbedaan dengan belajar yang sama sekali tidak menggunakan keterampilan proses.

Dengan demikian interaksi yang nyata hanya terjadi antara pembelajaran dengan keterampilan proses dengan siswa yang mempunyai motivasi tinggi terhadap hasil belajar IPA terpadu.

\section{PENUTUP}

\section{Kesimpulan}

Secara keseluruhan hasil belajar IPA terpadu siswa yang belajar melalui pendekatan keterampilan proses lebih tinggi daripada siswa yang dibelajarkan tanpa dengan penggunaan pendekatan keterampilan proses (pembelajaran konvensional). Temuan penelitian ini dapat disimpulkan bahwa dengan pendekatan keterampilan proses lebih efektif dan bermanfaat dalam meningkatkan hasil belajar IPA terpadu siswa tingkat SMP.

Hasil belajar IPA terpadu kelompok siswa yang memiliki motivasi tinggi lebih tinggi daripada kelompok siswa yang memiliki motivasi rendah. Temuan penelitian ini dapat disimpulkan bahwa motivasi belajar siswa memberikan kontribusi dalam meningkatkan hasil belajar IPA terpadu siswa tingkat SMP.

Terdapat interaksi yang nyata antara pendekatan keterampilan proses dengan motivasi terhadap hasil belajar IPA terpadu. Interaksi yang nyata tersebut terjadi pada A1B1 dibandingkan dengan A2B1. Dengan demikian dapat disimpulkan bahwa hasil belajar IPA terpadu siswa yang memiliki motivasi tinggi yang belajar dengan pendekatan keterampilan proses lebih tinggi daripada hasil belajar siswa yang memiliki motivasi tinggi yang tidak melalui pendekatan keterampilan proses (pembelajaran konvensional) (A1B1>A2B1). Demikian pula A1B1 dibandingkan A1B2 dengan demikian dapat disimpulkan bahwa hasil belajar IPA terpadu siswa yang memiliki motivasi tinggi dengan pendekatan keterampilan proses lebih tinggi daripada hasil belajar siswa yang memiliki motivasi tinggi yang belajar dengan tidak melalui pendekatan keterampilan proses (pembelajaran konvensional), A1B1 - A1B2). Dari temuan penelitian ini dapat disimpulkan bahwa untuk meningkatkan hasil belajar pada siswa yang memiliki motivasi tinggi dapat digunakan dengan pembelajaran melalui pendekatan keterampilan proses.

Terdapat perbedaan hasil belajar siswa yang jelas dan nyata dengan menggunakan pendekatan keterampilan proses dengan motivasi rendah dapat tercapai? Dari temuan penelitian ini dapat disimpulkan bahwa bagi siswa yang mempunyai motivasi rendah harus dilaksanakan pembelajaran dengan pendekatan keterampilan proses supaya haril belajar dapat tercapai sesuai dengan apa yang diharapkan. 


\section{Saran}

Perlu penelitian lebih lanjut untuk mengetahui pendekatan pembelajaran yang lebih tepat untuk meningkatkan hasil belajar pada siswa yang memiliki motivasi rendah. Sebelum proses pembelajaran berlangsung disarankan guru mengetahui informasi mengenai tingkat motivasi belajar siswa.

Dalam proses belajar mengajar dengan menggunakan pendekatan keterampilan proses IPA, para guru sebaiknya membuat rencana pembelajaran. Dalam perencanaan ini ditentukan semua konsepkonsep yang dikembangkan, dan untuk setiap konsep ditentukan metode atau pendekatan yang akan digunakan serta keterampilan proses IPA yang akan dikembangkan.

Dengan bekal hasil penelitian ini, maka disarankan guru merancang dan mengembangkan sendiri pendekatan pembelajaran keterampilan proses dalam penyusunan silabus dan RPP.

Penilaian hasil belajar siswa disarankan untuk dilakukan secara berkala, salah satunya dengan cara mengembangkan instrumen hasil belajar dengan berbagai variasi bentuk tes.

Dalam upaya meningkatkan motivasi belajar siswa, maka disarankan guru lebih menyenangkan, tidak kaku, ramah, tidak memberikan tugas yang memberatkan, menjelaskan tujuan pembelajaran umum dan khusus yang ingin dicapai, memberikan pujian atau hadiah, kepada siswa yang dapat menjawab atau mengerjakan soal, dan menciptakan suasana kelas yang menyenangkan dan nyaman untuk berlangsungnya proses pembelajaran.

Dalam meningkatkan hasil belajar, seorang guru harus mengetahui karakteristik anak (salah satunya tingkat motivasi) sehingga guru dapat menggunakan media dan proses pembelajaran yang tepat atau sesuai dengan karakteristik siswa tersebut.

\section{DAFTAR PUSTAKA}

Anderson, Lorin W. and Krathwohl, David R. (2001). A Taxonomy for Learning, Teaching and Assessing, A Revision of Bloom's Taxonomi of Educational Objectives. New York: Longman Inc.

Sulistyorini, Ari. (2009). Biologi I. Jakarta: Pusat Perbukuan, Departemen Pendidikan Nasional.

Davies, Ivor K. (1981). Instructional Technique. New York: Mc Graw - Hill Book Company.

Hasibuan, H. dan Malayu, SP. (2004). Organisasi dan Motivasi. Jakarta: Bumi Aksara

Jaali. 2008. Psikologi Pendidikan. Jakarta: Bumi Aksara

Johnson, Elaine B. (2002). Contextual Teaching and Learning: What is is and why it's here to stay. United States of America: Corwin Press, Inc.

Kemp, Jerrold E. (1996). Instructional Design. California: Fearon - Pitman Publisher.

Makmun, Abisn Samsuddin. (1999). Psikologi Pendidikan. Bandung: Remaja Rosdakarya.

Panduan Lengkap KTSP. (2007). Kurikulum Tingkat Satuan Pendidikan. Jogjakarta: Pustaka Yustisia.

Panduan Lengkap KTSP Perangkat Pembelajaran Sekolah Menengah Pertama (SMP,Madrasah Tsanawiyah (MTS).

Soedijarto. (1993). Menuju Pendidikan Nasional Relevan dan bermutu, Jakarta: Balai Pustaka.

Soekamto, Toeti. (1993). Perancangan dan Pengembangan Sistem Instruksional. Jakarta: Intermedia.

Uno, Hamzah B. (2007). Teori Motivasi dan Pengukurannya. Jakarta: PT Bumi Aksara.

Usman, Moh. Uzer. (1995). Menjadi guru Profesional. Bandung: PT. Rosda Karya.

Woolfolk, Anita E. (1993). Educational Psychology. Boston: Allyn \& Bacon.

Riyanto, Yatim. 2007. Metodologi Penelitian Pendidikan. Surabaya: SIC. 